\title{
DO MAL-ESTAR SOCIAL AO MAL- ESTAR DOCENTE: CONTRIBUIÇÕES DA PSICANÁLISE
}

\author{
Yara Magalhães dos Santos (UFU)* \\ http://orcid.org/0000-0001-6247-658X
}

\section{RESUMO}

Este artigo analisa o mal-estar entre professores a partir da perspectiva psicanalítica. São apresentados resultados de uma pesquisa, realizada entre os anos de 2011 e 2013, com professores do ensino médio, na cidade de Uberlândia, MG, na qual foram realizadas entrevistas no intuito de compreender possíveis razões do mal-estar entre professores. Compreendendo o mal-estar como fenômeno social maior, buscamos analisar motivações relacionadas a sintomas típicos do mal-estar docente, como apatia, sofrimento, adoecimento e outros. Com apoio na Psicanálise Freudiana estabelecemos uma relação entre o malestar social e fenômeno sociais que atingem o contexto escolar, e que eclodem em sofrimento psíquico para muitos docentes. Verificamos que algumas razões do mal-estar estão associadas às falhas do processo educacional enquanto operador de interdição dos alunos e ambivalência de sentimentos em relação à profissão, que ora assume contornos de culpa e autoagressão. Concluímos que o cenário escolar aspira contribuições para reflexões acerca dos processos de interdição social e da própria análise do mal-estar, enquanto dilema que extrapola os muros da escola.

Palavras-chave: Mal-estar. Mal-estar docente. Psicanálise e Educação.

\section{ABSTRACT}

\section{FROM SOCIAL DISCONTENTE TO TEACHING DISCONTENTE: CONTRIBUTIONS FROM PSYCHOANALYSIS}

This article analyzes the discontent among teachers from a psychoanalytic perspective. Results of a survey, carried out between 2011 and 2013, with high school teachers in the city of Uberlândia-MG, are presented, in which interviews were carried out in order to understand possible reasons for the discontent among teachers. Understanding the malaise tha resulted of this discontent as a social phenomenon, we seek to analyze motivations related to typical symptoms of teacher malaise, such as apathy, suffering, illness and others. With support in Freudian Psychoanalysis, we established a relationship between social discontent and social phenomena that affect the school context, and that 
create psychological distress for many teachers. We found that some reasons for the malaise y discontent are associated with the failures of the educational process as an operator of psychic interdiction of students and ambivalence of feelings in relation to the profession, which can represent guilt and self-harm. We conclude that the school scenario needs contributions to reflections about the processes of social interdiction and the analysis of teacher malaise itself, as a dilemma that goes beyond the school walls.

Keywords: Discontent social. Teacher discontent. Psicoanálisis y Educación.

\section{RESUMEN}

\section{DEL MALESTAR SOCIAL AL MALESTAR DOCENTE: CONTRIBUCIONES DEL PSICOANÁLISIS}

Este artículo analiza el malestar entre los docentes desde una perspectiva psicoanalítica. Se presentan los resultados de una investigación, realizada entre 2011 y 2013, con profesores de secundaria en la ciudad de Uberlândia-MG. Se realizaron entrevistas para comprender posibles razones de malestar entre los docentes. Al entender el malestar como un fenómeno social, buscamos analizar las motivaciones involucradas con los síntomas típicos del malestar de profesores, como la apatía, el sufrimiento y enfermedad. Con el apoyo del psicoanálisis freudiano, establecimos una relación entre el malestar social y los fenómenos sociales que afectan el contexto escolar y que provocan angustia psicológica para muchos maestros. Descubrimos que algunos motivos del malestar están asociados con los fracasos del proceso educativo como operador de interdicción psicológica de estudiantes y ambivalencia de sentimientos en relación con la profesión, que supone culpa y autolesión. Llegamos a la conclusión de que el escenario escolar necesita reflexiones sobre los procesos de interdicción social y el análisis del malestar como un dilema que va más allá de los muros escolares.

Palabras clave: Malestar. Malestar docente. Psicoanálisis y Educación.

\section{Considerações iniciais}

De todos os lados, por todos os meios de comunicação, em grande parte de nossas experiências contemporânea, somos invadidos por dilemas que, de uma forma ou de outra, resvalam no mal-estar que a civilização humana vive nessas primeiras décadas do século XXI. Não foi diferente nas derradeiras décadas do século passado. 0 termo "mal-estar" nos remete, sobretudo, à perspectiva freudiana, contemplada na célebre obra Mal-estar na civilização (FREUD, 1996c), de 1930, na qual o autor fala sobre como a construção ordeira e pacífica da civilização nos coloca diante do mal-estar fruto da impossibilidade de satisfação pulsional plena.

Do século XIV até os dias atuais, a sociedade se transformou, e aquela cultura repressora, baseada na interdição do gozo a acompanhou nessas mudanças. Não obstante, de maneira individual e comunitária continuamos atingidos por diversos mal-estares que revelam novos dilemas de nossa convivência social.

Esse sentimento de mal-estar está presente de forma muito peculiar nos contextos escolares. Não é incomum, ao presenciar uma conversa formal ou informal entre professores, 
ouvirmos o descontentamento e as queixas relacionadas ao exercício do magistério, queixas relacionadas à indisciplina dos alunos, violência escolar, desvalorização profissional, perda de autoridade do professor, além de outras. São queixas que denunciam o desconforto, o sofrimento e a angústia que podem caracterizar uma espécie de crise no ambiente escolar, marcada pelo sentimento de um mal-estar.

Como profissional da Psicologia, tenho ocupado há algum tempo o espaço de escuta para a angústia que parte de alguns professores que lecionam no ensino básico, sobretudo dos que lecionam no ensino médio. São queixas que denunciam um mal-estar docente, e que aparecem de forma muito peculiar em profissionais do ensino médio, como recorrentes questionamentos em relação à rotina de se deslocar entre várias instituições, à má-formação do ensino básico, à cobrança em relação à aprovação dos alunos nas universidades e a conflitos entre professores e alunos.

Tais apontamentos demonstram como as proposições psicanalíticas sobre o mal-estar são atuais para análise dos dilemas que atingem as escolas. Com base nessa perspectiva teórica, nossa pesquisa ${ }^{1}$ buscou analisar questões que motivam o mal-estar entre professores do ensino médio, na cidade de Uberlândia, MG. A partir de fontes orais resultadas das entrevistas realizadas, analisamos como o mal-estar se manifesta entre os professores, e quais questões eles evidenciam como fonte de angústia e sofrimento proveniente do exercício profissional.

\section{0 mal-estar na perspectiva de Sigmund Freud}

0 mal-estar foi apontado e analisado por Freud (1996c) em seu texto escrito em 1930, $O$

1 Por se tratar de uma pesquisa com seres humanos, o projeto de investigação foi submetido ao Comitê de Ética em Pesquisas com Seres Humanos da Universidade Federal de Goiás (UFG), instituição à qual a autora estava vinculada na ocasião do desenvolvimento da pesquisa, como aluna do Programa de Pós-graduação em Educação (mestrado). mal-estar na civilização, no qual o autor descreve a existência de um mal-estar generalizado em toda a sociedade civilizada. Esse mal-estar referenciado por Freud alude a um estado de sofrimento que pode ou não se manifestar por meio de patologias.

Para o pai da psicanálise, todo sofrimento é uma sensação que existe na medida em que as pessoas o sentem. Esse sentimento decorre dos modos pelos quais o organismo está regulado, o que remete à busca pelo prazer. 0 desprazer, nesse sentido, estaria necessariamente associado ao sofrimento. Assim, o sofrimento humano pode se desenvolver por três origens distintas: pelo próprio corpo, pelo mundo externo e pelo relacionamento entre os homens (FREUD, 1996c).

O corpo, por si, apenas caminha para a decadência e dissolução, apresentando o sofrimento como um sinal ou advertência. Já o mundo externo pode voltar-se contra os indivíduos através de forças destruidoras, como é o caso dos desastres naturais. E, por fim, os próprios relacionamentos estabelecidos entre os homens seriam fonte de sofrimento. Segundo Freud (1996c, p. 85), esta última trajetória para o sofrimento seria mais penosa que qualquer outra, já que tende a ser interpretada pelas pessoas como "uma espécie de acréscimo gratuito", algo que parece ser inevitável para aqueles que convivem na sociedade civilizada, tendo em vista que, enquanto conviver em um grupo normatizado por regras sociais, o homem sofrerá.

0 reconhecimento das duas primeiras fontes de sofrimento indica possibilidades para a ação humana, uma vez que os indivíduos têm a possibilidade de se afastar delas (não totalmente) e aliviar uma parcela desse sofrimento. Já a terceira fonte de sofrimento, referente ao convívio social, tem se constituído ao longo da história como um grande infortúnio que a civilização carrega, fruto do próprio arranjo de construção da civilização e da manutenção dos vínculos sociais. Esse infortúnio se expressa pelo mal-estar compartilhado nas 
sociedades que experimentaram os processos civilizatórios.

A tentativa de adequação individual às regras sociais causa sofrimento na medida em que é necessário abrir mão de uma parcela de satisfação em benefício de um bem almejado para o grupo, de modo que, para atender as normas sociais, o homem passa a se autorregular, sendo, muitas vezes, o próprio agente de sua castração.

Na primeira perspectiva, o mal-estar decorreria da impossibilidade da coexistência da satisfação pulsional plena do indivíduo e da constituição ordeira e pacífica da civilização. Civilização seria "tudo aquilo em que a vida humana se elevou acima de sua condição animal e a difere da vida dos animais" (FREUD, 1996c, p. 15). 0 estado de civilização da sociedade serviria a dois objetivos: o de proteger os homens contra a natureza e o de regular os relacionamentos sociais entre os homens (FREUD, 1996c).

Nas últimas décadas, o homem alcançou vários avanços culturais e tecnológicos que o permitiram exercer algum controle sobre a natureza, e que, de certa forma, contribuíram para a economia de sua felicidade. No entanto, essas conquistas não se traduziram no equivalente aumento de possibilidades de satisfações prazerosas (FREUD, 1996c). Alguns avanços tecnológicos possibilitam formas de satisfação limitadas. Contudo, Freud (1996c) ressalta que essas satisfações seguem o modelo do "prazer barato", assim como aquele que provoca uma ação desprazerosa para ter o prazer de invertê-la ou solucioná-la.

A civilização não foi uma evolução natural da vida humana, ao contrário, foi uma construção empreendida pelo próprio homem ao longo dos anos. Freud (1996c) não trabalha com a ideia de que a civilização é equivalente a uma evolução humana. Esse autor concorda que, com a civilização, o homem ganhou muitos benefícios, elevou o conhecimento e a capacidade de controlar as forças da natureza, além de organizar inúmeras formas de extrair riquezas naturais para satisfazer suas necessidades. Entretanto, com a civilização, os homens também construíram regras que normatizam a convivência em sociedade, as quais, em geral, impedem a satisfação plena dos desejos humanos, o que, para esse autor, representa um dilema na história de constituição das sociedades: prazer ou sobrevivência da cultura, da sociedade? É essa questão que alimenta o eterno conflito entre indivíduo e pulsão, visto que os homens, ao aderirem ao convívio em sociedade, passam a desejar essa convivência, sem, no entanto, conseguirem calar o desejo de satisfação pulsional que muitas vezes se contradiz com as normas que regulam e orientam as relações sociais.

As normas sociais incluem "todos os regulamentos necessários para ajustar as relações dos homens uns com os outros e, especialmente, a distribuição de riquezas" (FREUD, 1996b, p. 16). Esses regulamentos que ajustam a vida em sociedade são necessários para a manutenção da civilização, visto que regulam não apenas a distribuição de riquezas, mas também as relações entre homens, de forma a protegê -los contra seus próprios impulsos hostis, que poderiam se opor aos avanços sociais do grupo.

Aplicadas aos relacionamentos humanos, as normas atendem aos mesmos propósitos de privação dos instintos naturais. Em tempos de barbárie, os relacionamentos estavam sujeitos à arbitrariedade do indivíduo mais forte. Com o avanço da civilização, o fator de decisão pela força individual foi trocado pela força de um grupo. Sobre isso, Freud (1996c, p. 130) descreve:

A substituição do poder do indivíduo pelo poder de uma comunidade constitui o passo decisivo da civilização. Sua essência reside no fato de os membros da comunidade se restringirem em suas possibilidades de satisfação ao passo que o indivíduo desconhece tais restrições. A primeira exigência da civilização, portanto, é da justiça, ou seja, a garantia de que uma lei, uma vez criada, não será violada em favor de um indivíduo.

Na civilização o homem não é essencialmente livre; sua liberdade é sempre restrita e cheia 
de imposições. 0 indivíduo está sempre preso a normas e leis, refém da culpa e de punições contra si mesmo ou outrem. Isso não significa que haja no pensamento freudiano uma apologia à vida humana primitiva, ou ao retorno da sociedade pré-civilizada. Mesmo apontando os prejuízos causados ao homem pela civilização, o próprio Freud reconheceu que o homem primitivo e livre não se encontrava em estado melhor que o homem civilizado, como pode ser verificado no trecho abaixo:

Se a civilização impõe sacrifícios tão grandes, não apenas à sexualidade do homem, mas também à sua agressividade, podemos compreender melhor porque lhe é difícil ser feliz nessa civilização. Na realidade, o homem primitivo se achava em situação melhor, sem conhecer restrições de instinto. Em contrapartida, suas perspectivas de desfrutar dessa felicidade, por qualquer período de tempo, eram muito tênues. O homem civilizado trocou uma parcela de suas possibilidades de felicidade por uma parcela de segurança. Não devemos esquecer, contudo, que na família primeva apenas o chefe desfrutava da liberdade instintiva; o resto vivia em opressão servil. [...]. Quanto aos povos primitivos que ainda hoje existem, pesquisas cuidadosas mostraram que sua vida instintiva não é, de maneira alguma passível se ser invejada por causa de sua liberdade. Está sujeita a restrições de outra espécie, talvez mais severas do que aquelas que dizem respeito ao homem moderno. (FREUD, 1996c, p. 119 -120).

Reconhecendo que a privação e a opressão fazem parte da vida em grupo, mesmo que não civilizada, seria utópico e errôneo imaginar que o não estado de civilização concederia aos homens uma fuga para o mal-estar. A crítica freudiana à civilização não pode ser levada ao extremismo. 0 psicanalista reconhece as benfeitorias da civilização para a humanidade e determina que, ao criticar o modelo de civilização, não se pode considerá-lo como um "inimigo da civilização".

$\mathrm{O}$ dilema indivíduo $\mathrm{X}$ civilização é amplamente discutido por Freud. Esse autor, que viveu entre o final do século XIX e início do século XX, experimentou a extrema repressão de uma época em que as possibilidades de satisfação eram muito limitadas. Por isso o esforço do psicanalista em mapear a história e o processo da civilização, sem, contudo, desejar a renúncia dessa condição social.

Sua análise sobre a história e o processo de civilização mostra como a adaptação ao convívio social exige do ser humano a renúncia ao instinto humano. A manutenção da sociedade civilizada pressupõe "exatamente a não-satisfação (pela opressão, repressão, ou algum outro meio?) de instintos poderosos" (FREUD, 1996c, p. 104). No entanto, mesmo quando reprimidos, o desejo e a vontade de satisfazê -los não deixam de existir. Esse desejo forçado à repressão passa a existir sob uma dinâmica inconsciente que permanece a atravessar o sujeito. 0 fato de um sujeito ser forçado a viver sem satisfação pulsional plena não implica que essa se anulará. Mesmo com repressão, algo sempre resta nessa tentativa, e dessa frustração resulta o mal-estar.

Freud (1996c) ressalta que todos os indivíduos sofrerão, no mínimo, um mal-estar decorrente da frustração, da não satisfação pulsional plena. Dessa forma, ele afirma que se paga um preço pelos avanços que a civilização concedeu ao homem e ressalta que "não é fácil entender como pode ser possível privar de satisfação um instinto. Não se faz isso impunemente. Se a perda não for economicamente compensada, pode-se ficar certo de que sérios distúrbios decorrerão disso" (FREUD, 1996c, p. 104).

Apesar das benfeitorias originadas pelos avanços sociais associados ao processo de civilização, ao aderir à vida em comunidade os homens aderem também a uma condição de sofrimento, caracterizada pelo conflito entre sociedade e pulsão, ou, como o psicanalista Raulet (2002) denomina, a equação civilização -renúncia, ou seja, aderir à civilização implica renunciar. Carrega-se o fardo da renúncia em troca das vantagens da lei comunitária, como a segurança.

Por isso, o discurso incisivo sobre os prejuízos dos ideais civilizatórios não ofusca o 
desconforto que nos atinge quando observamos falhas no jogo proibitivo da satisfação irrestrita dos desejos humanos, ou seja, quando não observamos a renúncia. Quando acostumados com a cultura do enaltecimento da bondade, dos valores cristãos e do "politicamente correto", observamos as manchetes de jornal que trazem à tona a criminalidade, a violência e a esbórnia, não deixamos de olhar, estarrecidos, o desvio da ordem social e a falha do processo civilizatório. Legitimamos a troca da liberdade individual pela segurança, e as possíveis ameaças a essa segurança também nos provocam mal-estar.

É estabelecido, então, um constante e ininterrupto jogo contraditório, uma guerra de forças entre desejos e exigências para a vida em comunidade. Ao mesmo tempo em que sofremos pelas renúncias que devemos fazer, desejamos a condição da civilização e esperamos da comunidade as mesmas renúncias. São mal-estares que surgem nas relações entre os desejos pessoais e entre os sujeitos, as quais fundam a própria constituição humana. Em outras palavras, todo indivíduo experimenta o mal-estar e se constituiu enquanto sujeito também a partir dessa experiência.

Todavia, vale ressaltar que a relação entre civilização e pulsão é marcada não apenas pela repressão. A carga pulsional inibida (a libido) é desviada para atividades úteis para a comunidade, e que, assim, ajudam a fundar a civilização (RAULET, 20002, p. 73). Trata-se, então, de uma repressão individual, que passa a ser útil para a vida comunitária, sobretudo porque a condição humana se apoia na luta de duas pulsões originárias, a de Eros e a de morte. Enquanto a primeira atua com o intuito de "preservar a substância viva e para reuni-la em unidades cada vez maiores", a última atua de maneira contrária, "buscando dissolver essas unidades e conduzi-las de volta a seu estado primevo e inorgânico" (FREUD, 1996c, p. 122). É como se a civilização atendesse a um propósito de Eros.

Para Freud (1996c), as manifestações do instinto de vida, Eros, eram claramente per- ceptíveis; já as manifestações do instinto de morte não eram tão visíveis, mas era possível pensar em sua participação nos processos que envolviam a agressividade humana. Assim, uma parte do instinto de morte seria desviada do seu sentido ao mundo externo, dando origem a um instinto de agressividade e destrutividade. Contudo, essa força destrutiva poderia agir a favor da manutenção da vida, e, assim, estar a serviço de Eros. Freud (1996c, p. 122) conclui que "os fenômenos da vida podiam ser explicados pela ação concorrente, ou mutuamente oposta, desses dois instintos".

Dessa maneira, o próprio instinto poderia ser compelido para o serviço de Eros, no caso de o organismo destruir alguma outra coisa, inanimada ou animada, em vez de destruir o seu próprio eu (self). Inversamente, qualquer restrição desta agressividade dirigida para fora estaria fadada a aumentar a autodestruição, a qual, em todo e qualquer caso prossegue. Ao mesmo tempo, pode-se suspeitar, a partir deste exemplo, que os dois tipos de instinto raramente - talvez nunca - aparecem isolados um do outro, mas que estão mutuamente mesclados em proporções variadas e muito diferentes, tornando-se assim irreconhecíveis para nosso julgamento. (FREUD, 1996c, p. 123).

Entende-se, pois, que o homem apresenta uma "inclinação para a agressão", uma "disposição instintiva original e auto-subsistente" que seria o maior impedimento à civilização (FREUD, 1996c, p. 125). A civilização constitui, desse modo, "um processo a serviço de Eros, cujo o propósito é combinar indivíduos humanos isolados, depois famílias e, depois ainda raças, povos e nações numa única grande unidade, a unidade da humanidade" (FREUD, 1996c, p. 126).

Contudo, se a civilização atende a um propósito de Eros, o mal-estar que dela decorre é fruto da eterna ambiguidade humana e da luta entre as pulsões de vida e de morte. Sendo assim, se o mal-estar faz sofrer, tal como o psicanalista Raulet (2002, p. 73), podemos indagar se "a despeito de todas as técnicas, sublimações, e ilusões inventadas pelos indiví- 
duos" os homens continuam a sofrer mal-estar, "qual necessidade direciona a civilização para essa via?" É o sobressalto do instinto de vida sobre o instinto de morte, tal como explica Freud (1996c, p. 126):

Agora, penso eu, o significado da evolução da civilização não mais nos é obscuro. Ele deve representar a luta entre Eros e a Morte, entre o instinto de vida e o instinto de destruição, tal como ela se elabora na espécie humana. Nessa luta consiste essencialmente toda a vida, e, portanto, a evolução da civilização pode ser simplesmente descrita como a luta da espécie humana pela vida.

A civilização, portanto, é o "Eros canalizado e adaptado, transformado em cimento social". Contudo, estará sempre exposta "aos ressurgimentos da agressividade" (RAULET, 2002, p. 75).

A inclinação à agressividade, derivada do instinto de morte, passa a assumir importância nas reflexões freudianas sobre o processo de civilização, pois traz à tona uma nova direção para o mal-estar, diferente daquela que foca a repressão das pulsões instintivas humanas. É a segunda perspectiva trabalhada por esse autor sobre as razões do mal-estar, na qual a atenção passa "das forças reprimidas para as forças repressoras" (FREUD, 1996c, p. 122).

A inibição dos impulsos de agressividade, que tende a ser direcionada para fora do sujeito, mas que é reprimida para possibilitar a convivência social, leva à introjeção de uma parcela dessa hostilidade, que, quando internalizada, ajuda a compor o superego. Esse, por sua vez, passa a atuar contra o ego do próprio sujeito e conta com a agressividade internalizada para essa atuação.

Ou seja, esse impulso agressivo e hostil não se anula, mas, em parte, passa a operar contra o próprio sujeito, como agente de regulação através do superego. Freud (1996c, p. 144) também postula a existência de um superego da comunidade "sob cuja influência se produz a evolução cultural". Esse superego desenvolveu os ideais e as exigências da cultura e algumas dessas exigências foram denominadas de ética. Para Raulet (2002, p. 79), os efeitos desse superego coletivo podem provocar "neuroses nas escalas de civilizações inteiras".

\section{Mal-estar na atualidade: o que nos conta a psicanálise sobre 0 mal-estar contemporâneo}

É necessário descrever algumas ressalvas sobre o momento histórico em que Freud (1996c) escreveu sua obra $O$ mal-estar na civilização e sobre os dias atuais. A contemporaneidade não é caracterizada pela mesma repressão dos anos vividos por esse autor. Assistimos outras configurações sociais: o gradual declínio das figuras externas de opressão e autoridade; a alimentação do discurso de liberdade; o rompimento com os valores tradicionais; o culto aos excessos e às compulsões; o imediatismo de uma cultura marcada por imagens estéticas do sucesso e do consumo, tudo isso contribui para novas configurações da subjetividade que muito se difere da sociedade europeia do início do século XX. Para a psicanalista De Paoli (2005, p. 41), todas essas transformações sociais e culturais apontam para o fato de que o superego, aquela instância antes repressora e interditora do gozo sem limites, estaria igualmente em transformação.

Matteo (2011, p. 284), psicólogo e filósofo, afirma observar fortes indícios de que o "superego cultural de que nos fala Freud foi substituído por um novo tipo aparentemente mais fraco, mais liberal, menos exigente e culpabilizador, mais tolerante e permissivo, mais afinado com nossa sociedade de consumo", igualmente mais flexível e liberal.

De fato, a nova configuração social do ocidente, no século XXI, reflete uma sociedade que saiu da extrema repressão para uma sociedade das inúmeras possibilidades de gozo. Pereira (2009, p. 43) afirma que "há um transbordamento de gozo na ordem cínica do mercado, na obsessão moral pela eficácia técnica e 
disciplinar, no fundamentalismo religioso e no paradigma apolítico do individualismo". Individualismo alimentado pela fragmentação, que cria terreno para o surgimento de novas formas de subjetivação.

Birman (2009, p. 23) afirma que, em todas as "novas maneiras de construção da subjetividade, o eu se encontra situado em posição privilegiada", é o "autocentramento" do eu. No entanto, esse "autocentramento" não ocorre por vias de interiorização do sujeito, ao contrário, demarca uma nova configuração subjetiva, em que o "autocentramento" passa a ter o "valor da exterioridade" (BIRMAN, 2009, p. 23).

Isso significa que a construção de subjetividades narcísicas também serve a um propósito de exibição ao outro. É a sociedade do espetáculo. 0 olhar do outro torna-se importante para a economia psíquica dos indivíduos, e o desejo passa a transitar por uma direção marcada pelo "exibicionismo" e pelo "autocentramento", contribuindo para a construção de subjetividades esvaziadas, sem investimento em trocas inter-humanas (BIRMAN, 2009). Nesse cenário, o que resta a essas novas subjetividades senão o estabelecimento de "pequenos pactos em torno da possibilidade de extração do gozo" (BIRMAN, 2009, p. 24), seja na relação com o corpo alheio, com o capital, com o trabalho, ou outros? É a ordem do prazer barato e imediato.

Se uma cultura mais flexível possibilitou o surgimento de autoridades externas e internas menos rígidas, os ideais civilizatórios estão cada vez mais presentes, transformados em ideias de "sucesso" no mundo atual. Há autoridades internas e externas que continuam a exigir, mas que, agora, exigem os ideais esperados em nossa cultura, sejam eles o capital, o poder simbólico da academia, o sucesso, a popularidade, os relacionamentos afetivos, ou seja, possibilidades imediatas sempre atreladas ao gozo como um "imperativo categórico", exercido por um superego que ordena: "Goze!" (DE PAOLI, 2005, p. 449).

No entanto, são oferecidas tantas possibilidades de satisfação pulsional que os indivíduos não possuem tempo de ter acesso a todas. Estamos sempre atrasados para as possibilidades do gozo que nos são exigidas e que exigimos ter. Eis, então, um novo terreno para o mal-estar. Diante de tantas possibilidades e da cobrança social pelo gozo, o eu parece sentir-se impotente, nunca atende à expectativa, está sempre aquém.

\section{Do mal-estar Freudiano ao mal- estar docente}

Ao adotarmos a Psicanálise Freudiana como referencial teórico, concebemos o mal-estar docente como uma expressão peculiar no contexto educacional de um mal-estar social e cultural maior, que representa algo que funda a condição de sujeito em nossa sociedade.

Fora das instituições escolares, o mal-estar parece expressar-se de diferentes maneiras. Para Pereira (2009, p. 43), psicólogo e pesquisador das interfaces entre Psicologia e Educação, "nossa sociedade tem produzido, cada vez mais, novas formas de sintoma e angústia, espelhada em sua devoção aos excessos". Observamos o aumento dos fenômenos de violência, dos casos de vícios e dependências, da procura por respostas imediatas ou ilusórias, como a busca por auxílios transcendentais, e o gritante aumento dos diagnósticos de transtornos mentais, que exemplificam o que Pereira (2009) denomina como os modos atuais do sintoma social.

Em sendo a escola uma parte do todo social, esses modos atuais do sintoma social passam a ser observados em seu espaço de sociabilidade. Nesse cenário em que os professores parecem estar cada vez mais queixosos, desestimulados e adoecidos, o mal-estar parece eclodir nas práticas pedagógicas.

Ainda sim, nos parece necessário que nossa análise se inicie a partir da própria problematização do termo mal-estar. Tal discussão mostrou-se necessária na medida em que, na pesquisa de campo, quando procedíamos as apresentações formais da pesquisa, muitas 
pessoas questionavam o que seria o mal-estar docente que pesquisávamos naquele momento. Seria uma doença que atinge os professores? Seria o reflexo da insatisfação docente? Seria alguma síndrome, atualmente tão utilizada nos diagnósticos de mal-estar?

Ao longo da pesquisa de campo nos deparamos com diversas reações ao uso da terminologia, alguns professores consideravam que o termo carregava rastros negativos, que representava algo depreciativo, ainda que não o fosse. Já outros professores consideravam a expressão amena demais para denominar a atual crise que os atinge. 0 termo burnout ${ }^{2}$ foi frequentemente citado como uma espécie de sinônimo desse mal-estar, algo que parecia denominar de maneira mais evidente o sofrimento e desconforto que estavam a compartilhar.

De fato, quando se ouve o termo mal-estar docente pela primeira vez, sem o conhecimento das designações terminológicas da palavra, o pensamento imediato pode incorrer em associações, ou interpretações, quanto a possíveis indisposições físicas e incômodos que, de alguma forma, estejam associados à profissão docente.

Apesar de figurar frequentemente no campo da saúde como referência às perturbações fisiológicas e corporais, não é recente que o uso do termo sirva a outras discussões importantes de campos distintos da saúde física, fazendo referência a um mal-estar de ordem subjetiva. É com Freud (1996c) que o termo é ressignificado como forma de designar um estado subjetivo de sofrimento, um sentimento de falta que marca a construção de nossa condição social.

Birman (2009) auxilia-nos a compreender a discussão psicanalítica em torno do mal-estar ao afirmar que o texto freudiano trata de uma interpretação do mal-estar na modernidade, que se inscreve no campo da subjetividade, e que este é sempre matéria-prima para a produção do sofrimento.

2 Síndrome de burnouté um distúrbio psíquico categorizado no Código Internacional de Doenças (Z73.0) como uma síndrome de esgotamento físico e mental decorrente do exercício profissional (ORGANIZAÇÃO MUNDIAL DA SAÚDE, 2004).
O mal-estar mencionado por Sigmund Freud seria a angústia diante da configuração do modelo de civilização, caracterizado pela impossibilidade da coexistência da satisfação pulsional plena do indivíduo humano e a constituição ordeira e pacífica da sociedade moderna, e da angústia que surge em decorrência da operação de uma instância psíquica responsável pela regulação do sujeito frente às normas sociais.

Desde a publicação do texto $O$ mal-estar na civilização (FREUD, 1996c), em 1930, o termo mal-estar vem sendo apropriado por discursos de áreas distintas das da saúde ou da psicanálise propriamente dita. Podemos citar, aqui, discussões que fazem referência ao mal-estar no trabalho, na sociedade, na cultura geral, ao mal-estar do Capitalismo e, mais especificamente, o que interessa ao nosso estudo, a apropriação do termo mal-estar pela Educação, com a expressão mal-estar docente.

No campo educacional, discussões sobre um sentimento de mal-estar exclusivo da classe docente começaram a ser levantadas na década de 1980 por pesquisadores europeus que denunciavam uma crise na Educação. Na Europa, um dos maiores indicativos da crise referia-se à escassez de profissionais para suprir a demanda de trabalho existente (ESTEVE, 1999).

Para Esteve (1999, p. 25), o termo mal-estar docente é utilizado para descrever "os efeitos permanentes de caráter negativo que afetam a personalidade do professor como resultado das condições psicológicas e sociais em que se exerce a docência". Aqui, nota-se uma restrição aos possíveis efeitos na personalidade, mas na obra desse autor é possível observar que o termo mal-estar docente é utilizado para denominar todos os efeitos negativos que acometem o professor em decorrência do exercício profissional, efeitos que atingem não apenas a personalidade, mas, sobretudo, a saúde e o trabalho.

Quando o termo mal-estar aparece no campo da Educação, frequentemente é usado para designar toda e qualquer manifestação negativa que atinja o professor, sejam manifestações 
físicas, psíquicas, econômicas ou sociais, e que denunciem algo de errado na organização do trabalho docente que precise ser reparado.

Isso se evidencia quando Esteve (1999) compara a expressão mal-estar docente com o termo síndrome de burnout. Ele afirma que a literatura anglo-saxã convencionou utilizar o termo síndrome de burnout, que tende a ressaltar o caráter patológico associado ao estresse, para designar o mal-estar que acomete os professores. Entretanto ressalta que, apesar disso, o termo burnout corresponde ao termo mal-estar docente se for considerada a amplitude conceitual a qual o termo se refere. A expressão síndrome de burnout designa uma patologia, classificada no Código Internacional de Doenças como uma síndrome de esgotamento profissional. Verifica-se a proximidade com o discurso médico, que elege o mal-estar como um sintoma patológico.

Consideramos, então, que o conceito de mal-estar docente no campo da Educação algumas vezes não é fiel ao conceito do mal -estar freudiano. Algumas vezes, será usado para designar patologias, adoecimentos que, ainda que representem sintomas atuais para o mal-estar, não constituem exclusivamente o mal-estar alvo de nossa pesquisa.

Essa tem sido a perspectiva que tem guiado muitas pesquisas restritas ao campo da Educação, que não se apoiam em uma interpretação psicanalítica do mal-estar. Nessas, as causas do mal-estar tendem a ser colocadas no contexto social, na precarização e nas formas de organização do trabalho, sempre em algo do campo da realidade objetiva que deve ser reparado.

Nossa perspectiva considera o mal-estar como algo inerente à constituição do sujeito social, e, assim, como consequência, inerente à experiência de profissionais da Educação. No entanto, conceber o mal-estar como algo intrínseco à condição humana "não implica dizer que o sujeito deve existir necessariamente com perturbações do espírito, sejam estas da ordem da neurose, psicose ou perversão" (BIRMAN, 2009, p. 130). Significa, sim, "reconhecer que o sujeito deve fazer um trabalho infinito de gestão, justamente porque o desamparo originário da subjetividade seria incurável" (BIRMAN, 2009, p. 130).

Nesse sentido, entendemos que o mal-estar docente, enquanto expressão peculiar de um mal-estar social no contexto educacional, exige e exigirá de profissionais e pesquisadores da Educação esforços que procurem compreendê-lo a partir de sua dimensão subjetiva, que o coloca no centro das discussões psicanalíticas sobre nossa condição de sujeitos na sociedade.

Aguiar e Almeida (2008, p. 8) afirmam que é impossível ao sujeito “'produzir' mal-estar de forma individual, desvinculada das condições sociais de seu trabalho como docente e das relações interpessoais com o outro". 0 mal-estar se expressa de diversas formas: no adoecimento psíquico, no desinteresse pela profissão docente, na perda do sentido em ensinar, nas recorrentes queixas em relação à profissão, na ausência de profissionais do ensino etc. Todas essas manifestações são indícios de mal-estar entre a classe. É possível observar a ocorrência em que tais expressões acontecem: noticiários de TV, jornais locais ou acadêmicos denunciam cada vez mais a ausência de professores nas redes educacionais do Brasil. A ausência de professores se configura não apenas pela desistência da profissão, ou pelos afastamentos e licenças dos profissionais, mas principalmente pelo fato de que a carreira docente não tem atraído novos profissionais.

O aumento da ocorrência dessas expressões do mal-estar entre professores sugere que cada vez mais docentes, sobretudo os que lecionam no ensino básico, experimentam a angústia do mal-estar no exercício profissional. Jesus (2004) afirma que na atualidade existe uma espécie de crise de desmotivação e uma particular "crise de identidade" entre os professores, motivada pelas mudanças sociais e culturais que levaram a docência a perder o prestígio tradicional ao qual esteve associada por muitos anos. 


\section{Metodologia}

0 mal-estar docente, objeto de estudo desta pesquisa, é um fenômeno intrinsecamente subjetivo. Sua investigação implica o desenvolvimento de uma análise que não objetiva a generalização, ou o conhecimento de variáveis de causas ou consequências. Interessa-nos, portanto, investigar as formas de subjetivação do mal-estar, que ganha contornos diferentes em cada história que nos foi contada pelos professores.

Nossa pesquisa possui traços do método psicanalítico, mas não o adota de forma intrínseca e exclusiva. Primeiramente, porque este recorte investigativo não está situado em uma realidade clínica de análise do fenômeno. Para Herrmann (2004), a grande maioria das pesquisas com o método psicanalítico é realizada nos consultórios, durante o tratamento de pacientes, o que não foi, indubitavelmente, o nosso caso, e no que, também, não consistiu nossa pretensão. No entanto, o olhar psicanalítico que lançamos sobre o fenômeno do mal-estar e sobre a interpretação dos dados foi determinante.

As pesquisas com o método psicanalítico não estão restritas aos processos clínicos de análise e tratamento. 0 próprio Freud, pai da psicanálise, publicou mais de dois terços de trabalhos investigativos que não se tratavam de descrições de análises clínicas (HERRMANN, 2004).

A psicanálise dá nome a uma teoria, a uma técnica de tratamento e a um método de investigação, sendo este último essencialmente caracterizado pelo processo interpretativo (HERRMANN, 1999). Esse processo interpretativo não é restrito aos fenômenos psíquicos, mas a tudo o que existe e se manifesta no mundo.

Portanto, nossa pesquisa apresenta traços do método psicanalítico por se embasar em processos interpretativos, e por evocar na investigação do mal-estar a dimensão simbólica e inconsciente dos sujeitos entrevistados. Por isso, a relevância do olhar psicanalítico para o mal-estar, bem como de uma escuta psicanalítica que rompa com o discurso expresso e que possibilite a construção de caminhos até esse universo simbólico.

Joel Birman (2009, p. 15), ao lançar discussões sobre o mal-estar na atualidade, o descreve como aquilo que produz sofrimento, e afirma que, ao se propor "empreender uma cartografia esquemática do mal-estar em nossa contemporaneidade", o sujeito sofrente torna-se o horizonte de análise. Por isso a importância de se resgatar esse sujeito e dar voz a esse mal-estar, na tentativa de compreender os sentidos por eles atribuídos a esse fenômeno.

0 acesso a esses significados e a essa dimensão simbólica é possível por via do discurso. Por priorizar o discurso dos professores como fonte de acesso a esses dados sobre o mal-estar e seus desencadeadores, escolhemos a entrevista como ferramenta investigativa.

Foram realizadas entrevistas semiestruturadas com um grupo de 16 professores da rede de ensino médio de Uberlândia, $M G$, vinculados a escolas públicas (redes de ensino estadual e federal) e privadas. Para definir o número de professores a fim de compor a amostra, consideramos o número de escolas que ofereciam ensino médio e o número de professores ligados a esse serviço no município de Uberlândia, utilizando para isso dados do Instituto Brasileiro de Geografia e Estatística (IBGE). ${ }^{3}$

Definimos o número de entrevistados conforme a proporção entre as esferas estadual, federal e privada, de modo que a amostra para pesquisa foi composta como mostra a Tabela 1.

3 Na ocasião, segundo dados do IBGE - Cidades, Uberlândia possuía um total de 1.197 docentes vinculados ao ensino médio. Desse total, 851 docentes estavam inseridos nas escolas públicas estaduais, 23 docentes em uma escola pública federal, e 323 docentes nas escolas privadas (INSTITUTO BRASLEIRO DE GEOGRAFIA E ESTATÍSTICA, 2008). 
Tabela 1 - Composição da amostra para a pesquisa de campo

\begin{tabular}{|l|c|c|c|c|}
\hline \multicolumn{1}{|c|}{ Esfera das escolas } & Manhã & Tarde & Noite & Total \\
\hline $\begin{array}{l}\text { Escolas públicas } \\
\text { estaduais }\end{array}$ & $\begin{array}{l}2 \text { mulheres } \\
2 \text { homens }\end{array}$ & --- & $\begin{array}{l}2 \text { mulheres } \\
2 \text { homens }\end{array}$ & $\begin{array}{l}4 \text { mulheres } \\
4 \text { homens }\end{array}$ \\
\hline $\begin{array}{l}\text { Escolas públicas } \\
\text { federais }\end{array}$ & $\begin{array}{l}2 \text { mulheres } \\
2 \text { homens }\end{array}$ & --- & --- & $\begin{array}{l}2 \text { mulheres } \\
2 \text { homens }\end{array}$ \\
\hline Escolas privadas & $\begin{array}{l}2 \text { mulheres } \\
2 \text { homens }\end{array}$ & --- & --- & $\begin{array}{l}2 \text { mulheres } \\
2 \text { homens }\end{array}$ \\
\hline \multicolumn{2}{|c|}{ Total } & $\begin{array}{l}8 \text { mulheres } \\
8 \text { homens }\end{array}$ \\
\hline
\end{tabular}

Fonte: Elaborado pelos autores deste artigo.

\section{Resultados e discussão}

\section{Falhas do processo educacional como operador de interdição}

Nos relatos dos entrevistados, verificamos como o mal-estar pode ser provocado pelas falhas no processo educativo de adaptação às normas sociais. Como citamos anteriormente, o mal-estar entre professores, compreendido pelo viés psicanalítico, pode surgir a partir do que resta do recalque dos desejos que não podem ser satisfeitos e da constante cobrança do superego.

A primeira perspectiva, que compreende o mal-estar como resultado do conflito entre sociedade e pulsão, elege essa angústia como aquilo que sobra da repressão de alguns impulsos, de modo que, na impossibilidade da satisfação plena dos mesmos, tem-se o mal -estar. Podemos pensar em nossos docentes inseridos nesse contexto que preza justamente a não satisfação de impulsos importantes. No entanto, as entrevistas apontaram que o mal -estar sentido pelos professores está muito mais associado às falhas desse processo de regulação, ou seja, quando não há a adequada repressão de impulsos condenados pela ética social, impulsos hostis, por exemplo, e esses passam a ser direcionados aos professores por parte dos alunos. Então, aqueles professores, alvo dos impulsos hostis, sentem um mal-estar, o que tende a se acentuar quando esses mesmos professores continuam a manter, de forma rígida e coerente à ética social, o seu processo de regulação.

Denominamos a falha dessa repressão de falha do processo educacional, porque nisto se resumem os fins educacionais: moldar indivíduos conforme a ética social. Dessa forma, a escola pode ser considerada como uma das instituições mais expressivas criadas para atender ao ideal civilizatório. Levisky e Taille (2002, p. 109) consideram que, nas primeiras relações do processo educacional, os sujeitos criam "condições para o desenvolvimento de uma identidade, de padrões morais e éticos, das noções de liberdade e de democracia".

Ou seja, a educação, dentro e fora das escolas, configura-se como um expressivo agente de aprendizagem para a convivência social. A escola é, portanto, uma instituição que, no sentido geral, transmite alguns ideais culturais da civilização, nesse processo de adaptação ao convívio em sociedade. Inspirado em Freud, quando este demonstrou como surge o dilema que resulta em mal-estar, o psicanalista Voltolini (2011, p. 39) afirma que "a educação carrega em si a marca de um dilema que não é outro senão aquele que existe entre indivíduo e a civilização". 
Tanto os professores como os alunos estão subjugados à mesma norma social. 0 processo educativo foi construído em torno de um ideal de regulação de comportamento, e essa tentativa constante de regulação acaba por produzir conflitos e tensões permanentes que geram mal-estar entre professores e alunos, especialmente quando esses últimos, alvo do processo educativo, não correspondem aos ideais almejados pela Educação e pela cultura (MIRANDA; SANTIAGO, 2006). Trata-se, pois, de um mal-estar que surge não apenas pela renúncia pessoal à plena satisfação pulsional, mas, também, quando esta renúncia não é efetivada pelo outro.

Se os indivíduos continuam movidos pela pulsão no jogo de forças entre as instâncias psíquicas, é natural que esse processo de regulação fracasse algumas vezes. Assim sendo, o objetivo educacional nunca é completamente alcançado, porque não se consegue regular e interditar tudo, e a todo momento, da forma como propõe o ideal social. 0 próprio Freud já havia elegido a Educação como uma das profissões do impossível, junto ao ato de analisar e governar. Educar, do modo como os ideais sociais propõem, nunca é totalmente possível, pois não se regula, nem se reprime, sem que haja restos.

Sobre isso, é interessante recuperar a visão de Adorno (1995) sobre a relação entre Educação e os ideais civilizatórios da Educação. Ele afirma que o que a escola "pretende eliminar nos alunos, aquela natureza disforme", tende a retornar "como natureza oprimida nas idiossincrasias, nos maneirismos da linguagem, nos sintomas de estarrecimento, nos constrangimentos e nas inabilidades dos mestres" (ADORNO, 1995, p. 110), e que, por isso, o processo educacional sempre fracassou.

Esse fracasso do processo educacional tende a se voltar contra o professor de muitas maneiras. Às vezes, pela manifestação de atos condenados pela ética social, outras, pela frustração pessoal de alguém que reconhece que também falhou no seu objetivo de educar. Em muitos relatos, os professores apontaram evidências da falha da tentativa de regulação social no alunado, seja pela manifestação da violência, seja pelo comportamento da desordem. Vejamos, a seguir, alguns relatos de professores ${ }^{4}$ que revelam a angústia quando os alunos não efetivam a repressão de impulsos hostis.

[...] chegamos a assistir cenas até de quase agressões em sala de aula, de alunos que querem agredir os professores, e quando acontece isso, eu fico assim... muito indignado, triste mesmo. (JOÃO).

Ah, são os conflitos mesmo com os alunos. Hoje em dia é difícil. Os alunos não respeitam professor, discutem com professor, gritam, vira e mexe você ouve aí falar de professores que estão de licença porque brigaram com aluno, foram agredidos por aluno. (JOSÉ).

Teve uma última, um último embate. Assim, não foi embate porque eu também não vou, eu falo, não vou bater de frente no sentido de eu me machucar, eu me desgastar, até, às vezes, até fisicamente, né. Não quero perder a minha razão de bater boca com aluno, essas coisas. Eu prefiro ir embora ofendida do que pensar que eu dei um motivo pro aluno ter se sentido ofendido. [...] eu fiquei na sala de aula com o menino, com a, com a turma, e a turma, eu fiquei vinte e cinco, eu, eu marquei vinte e cinco minutos. Eu tentava falar, eu tentava conversar com eles: 'Oi pessoal, bom dia, tudo bem? Hoje a nossa aula, a dinâmica da nossa aula hoje é a seguinte'. Coisa que eu gastaria dois minutos, três pra dialogar com a turma, responder alguma pergunta que o aluno fizesse, eu fiquei vinte e cinco minutos tentando falar. Eles riam, zombavam, gritavam, um gritava de cá, o outro gritava de lá. Não era comigo, mas era pra mim, entendeu? Um falava uma coisa pro outro, e eles morriam de rir. E aquele negócio, ou, assim, eu não tenho palavras pra conseguir materializar, assim, o meu sentimento. E aí eu peguei [a professora começa a chorar]. (SIMONE).

Os relatos dos entrevistados revelaram, ainda, a opinião dos professores sobre a responsabilidade da falha em educar os alunos conforme os ideais sociais. Muitos docentes apontaram a sociedade geral e a família como

4 Os nomes dos professores utilizados na pesquisa são fictícios. 
as entidades que têm falhado nesse processo, que atinge as escolas através de questões como falta de limites, não reconhecimento de autoridade, manifestação de atos hostis e outras, como exemplificamos a seguir:

[...] nós temos uma cultura que ela não valoriza mais certos elementos, que, que, como eu diria, colocando em cheque se a educação é importante? Se você formar o caráter é importante, né? Já pensando na área que eu trabalho, a Filosofia, a ética, cidadania, tudo isso hoje tem um valor secundário [...] Então, é isso que deixa a gente um pouco... não desanima não, porque a gente não para por isso, mas é que torna o trabalho muito mais difícil, entendeu? Porque você tem toda uma organização que ensina o contrário [...] (JOAQUIM).

[...] a gente percebe nas famílias dos alunos. É claro que na família o pensamento da sociedade, então, isso que me dá um certo desânimo. Eu já passei por situações em que o aluno tem problema sérios de disciplina, mas é tipo de convívio social que aí não é só uma questão com um ou outro professor ou com algum funcionário da instituição, é dentro do próprio ambiente onde ele vive. Embora você remeta isso à família, a família não acredita, acha que não, que isso aqui é problema da escola, acha que o aluno não está satisfeito. Não sei se ela não tem essa percepção, ou se ela não quer enxergar esse problema, e muitos querem, queremos, acreditam que nós temos que resolver esse problema, né. E muitos querem que nós, acreditam que a gente que tem que resolver esse problema, que a gente tem que moldar o caráter do aluno, e não é assim. A família tem um papel fundamental no papel do caráter do indivíduo, e isso é desde de cedo, no início da vida da pessoa. 0 início dele é muito fechado dentro do convívio familiar. Eles abrem mão disso e, quando os problemas surgem, já na escola, eles querem que a escola resolva. Isso não procede, né. A escola não tem essa obrigação, não é esse o objetivo da escola. (MARTA).

Eu acho, assim, não foi a escola que falhou primeiro. Quem falhou primeiro foi a família, e a família tá falida, sabe, seja pelas mudanças que ocorreram aí no mundo do trabalho, que a mulher achou lindo sair de casa. Eu falo assim porque eu sou filha, eu sou filha de uma criação que a mãe ficou em casa, né, e eu acho que as pessoas, nesse movimento, perdeu-se, perde- ram-se os valores, quais valores, os valores de orientar o filho. A gente trabalha com crianças, e eu trabalho aqui nessa escola, né, trabalho com outras faixas etárias também, e, assim, você percebe que não tem a menor, que o menino vem pra escola, parece que a família cria e, assim, vai deixando tocar a lei da natureza, entendeu? E o menino chega na escola despreparado, mal-educado. Professor não tem, não tem autoridade, mas o professor só não tem autoridade é porque a família perdeu a autoridade. A mãe, a mãe, a gente chama às vezes, é, pais aqui na escola, [cita o nome da pesquisadora], e, quando a família chega, você vê que você tem mais respeito do menino, entendeu? Que o menino, todo o desrespeito que você entendeu que ele fez com você, ele ainda tá te respeitando mais do que tá respeitando a mãe dele que veio aqui, ou o pai. (SIMONE).

Esses relatos indicam que, na visão dos professores, a família e a sociedade em geral muitas vezes têm falhado na interdição dos filhos, seja na interdição dos desejos, seja dos impulsos hostis, e outros. A interdição é uma marca do discurso civilizador e da ética social para convivência comunitária. Dizer que a sociedade coloca sob suspeita a formação ética, que a família tem se esquivado do seu papel de formação de caráter, ou que as famílias têm educado os filhos à lei da natureza são relatos que remetem à Educação em seus princípios morais e que indicam a reivindicação dos professores por uma educação que consiga imprimir nesses alunos a marca da interdição.

Entretanto, porque requerer essa interdição que também causa mal-estar se ela nos leva a reprimir muitos de nossos desejos? Uma vez que os homens aderem à vida em comunidade $\mathrm{e}$ a legitimam, essa condição passa a ser concebida como ideal desejado. Por isso, por mais que inconscientemente alguns professores sintamse frustrados por estarem subjugados a tantas interdições das normas sociais, eles requerem do outro a mesma adaptação à essa ética social.

Nossas entrevistas sugerem que as falhas desse processo de regulação têm sido mais comuns entre os alunos. Dessa forma, os conflitos da relação entre professor e alunos estão 
entre os aspectos mais citados para as causas de mal-estar docente.

Em segunda instância, há também a constante cobrança que impede o reconhecimento das fragilidades e limitações, exigindo o sucesso o tempo todo. Os ideais culturais coletivos de sucesso navegam nesse universo simbólico da docência. Dos professores têm sido exigidas muitas funções, dentre as quais estão uma boa formação, qualificação constante, postura crítica, engajamento político e funções educacionais que atinjam resultados associados a tantos outros processos. E essas são apenas exigências profissionais, sem citar as demais, que passam por planos pessoais dos indivíduos. Como se alimentar de todas essas fontes? Os professores estão sempre atrasados, sempre aquém do que deveriam ser ou estar.

Segundo a psicanalista De Paoli (2005, p. 42), há uma "busca incessante de gozo sem limites como direito e também dever", ou seja, o gozo excede a categoria de direito e passa a ser percebido como um dever constante, assim, não tem como estar quite nunca. Da mesma maneira, não tem como o professor estar quite com tanto dever de satisfação que se apresenta em seu exercício profissional. Dessa forma, há uma tendência a autodepreciação, não revelada por nossos entrevistados em nível consciente, mas por nós apontada como uma possibilidade para possíveis reflexões.

\section{Culpa e autoagressão}

Retomando a questão apontada pela Psicanálise, do conflito indivíduo X civilização, algo parece resultar dessa equação, servindo de base para tantas outras neuroses, tais como evidenciaremos a seguir. Trata-se do sentimento de culpa. No jogo das renúncias pulsionais para convivência em sociedade, a instância do superego assume posição central.

No que tange à sua constituição, destaca-se a introjeção de uma parcela de agressividade. A inibição dos impulsos agressivos, que tendem a ser direcionados para fora do sujeito, mas são reprimidos para possibilitar a convivência social, leva à introjeção de uma parcela dessa hostilidade, que, quando internalizada, ajuda a compor o superego. Esse, por sua vez, passa a atuar contra o ego do próprio sujeito e conta com a agressividade internalizada para essa atuação. Esse processo é claramente descrito no trecho abaixo:

Outra questão nos interessa mais de perto. Quais os meios que a civilização utiliza para inibir a agressividade que se lhe opõe, torná-la inócua ou, talvez, livrar-se dela? [...] 0 que acontece neste para tornar inofensivo seu desejo de agressão? Algo notável, que jamais teríamos adivinhado e que, não obstante, é bastante óbvio. Sua agressividade é introjetada, internalizada; ela é na realidade, enviada de volta para o lugar de onde proveio, isto é, dirigida no sentido de seu próprio ego. Aí, é assumida por uma parte do ego, que se coloca contra o resto do ego, como superego, e que então, sob forma de 'consciência', está pronta para por em ação contra o ego a mesma agressividade rude que o ego teria gostado de satisfazer sobre outros indivíduos, a ele estranhos. (FREUD, 1996c, p. 127).

Ou seja, esse impulso agressivo e hostil não se anula, mas, em parte, passa a operar contra o próprio sujeito, como agente de regulação através do superego. Freud (1996c, p. 144) também postula a existência de um superego da comunidade "sob cuja influência se produz a evolução cultural". Esse superego desenvolveu os ideais e as exigências da cultura e algumas dessas exigências foram denominadas de ética. Para Raulet (2002, p. 79), os efeitos desse superego coletivo podem provocar "neuroses nas escalas de civilizações inteiras".

No que tange à atuação do superego, podese afirmar que sua força e agressividade contra o ego aumentam a cada renúncia instintiva, a cada "agressão de cuja satisfação o indivíduo desiste" (FREUD, 1996c, p. 131).

Com o superego, a vigilância em torno dos desejos e a pressão para sua renúncia passam a ser constantes. Tão logo o desejo se irrompe, o superego assume a posição de atuar contra ele, e o faz com a necessidade de punição, como descrito no trecho a seguir: 
A tensão entre o severo superego e o ego, que a ele se acha sujeito, é por nós chamada de sentimento de culpa; expressa-se com uma necessidade de punição. A civilização, portanto, consegue dominar o perigoso desejo de agressão do indivíduo, enfraquecendo-o, desarmando-o e estabelecendo no seu interior um agente para cuidar dele, como uma guarnição numa cidade conquistada. (FREUD, 1996c, p. 127).

O desejo é condenado e proibido por duas instâncias: a externa ao sujeito e a instância interna, representada pelo superego. "A primeira insiste numa renúncia às satisfações instintivas; a segunda, ao mesmo tempo em que faz isso exige punição, de uma vez que a continuação dos desejos proibidos não pode ser escondida do superego" (FREUD, 1996c, p. 131). Ocorre que o ser humano é um ser desejante, e se o desejo o atravessa, não é possível se livrar da condenação do superego, que o condena pela culpa e pela necessidade de punição.

Percebemos agora em que relação a renúncia ao instinto se acha com o sentimento de culpa. Originalmente, renúncia ao instinto constituía o resultado do medo de uma autoridade externa: renunciava-se à própria satisfação para não se perder o amor da autoridade. Se se efetuava essa renúncia, ficava-se, por assim dizer, quite com a autoridade e nenhum sentimento de culpa permaneceria. Quanto ao medo do superego, porém, o caso é diferente. Aqui, a renúncia instintiva não basta, pois o desejo persiste e não pode ser escondido do superego. Assim, a despeito da renúncia efetuada ocorre um sentimento de culpa. Isso representa uma grande desvantagem econômica na construção de um superego ou, como podemos dizer, na formação de uma consciência. Aqui, a renúncia instintiva não possui mais um efeito completamente liberador; a continência virtuosa não é mais recompensada com a certeza do amor. Uma ameaça de infelicidade externa perda de amor e castigo por parte da autoridade externa - foi permutada por uma permanente infelicidade interna, pela tensão do sentimento de culpa. (FREUD, 1996c, p. 131).

Mesmo quando não satisfaz o desejo em ato, o sujeito vivencia o sentimento de culpa, na maioria das vezes inconscientemente. $\mathrm{Na}$ tentativa de investigar a origem do sentimento de culpa, Freud (1996a) retoma algumas discussões descritas no texto Totem e Tabu para explicar uma suposta origem desse sentimento, que estaria relacionado ao complexo edipiano que retomaria a morte do pai primevo. Dessa discussão freudiana, precisamos destacar sua conclusão: a de que os sentimentos de culpa e o remorso ${ }^{5}$ são, quase sempre, resultados de um processo ambivalente, no qual o amor ao objeto também participa.

Isso significa que, se por vezes o sujeito, tomado do sentimento do ódio, destina impulsos agressivos a um objeto, fazendo alusão à figura edipiana, ao pai, esse mesmo sujeito, por outras vezes, também destina impulsos de amor. Está posta a ambivalência daquele que odeia, mas também ama. Disso podemos inferir que a relação dos professores com sua profissão também é marcada por essa ambivalência entre o amor e o ódio.

Se o sujeito exerce em ato de agressividade contra o objeto, é possível que, após a agressão, o amor retome o primeiro plano e, assim, a culpa e o remorso surjam em função do ato de agressão. Essa é a questão básica da qual se estende a explicação do sentimento de culpa e exigência da vida em comunidade.

A inevitabilidade da culpa e seu fortalecimento na vida em comunidade sugere que culpa e mal-estar estão intrinsecamente ligados. 0 próprio Freud (1996c, p. 137) elege a culpa como "o mais importante problema no desenvolvimento da civilização". Neste sentido, em uma leitura do mal-estar de professores, podemos indagar se não há uma pungente culpa por não exercerem suas funções docentes da forma como desejariam realizá-las.

Todavia é importante destacar que, mesmo sofrendo, muitos professores ainda reafirmam o seu desejo profissional, algo que revela a am-

5 Freud (1996c, p. 139-140) define remorso como "um termo geral para designar a reação do ego num caso de sentimento de culpa. Contém, em forma pouco alterada o material sensorial da ansiedade que opera por trás do sentimento de culpa; ele próprio é uma punição, ou pode incluir a necessidade de punição [...]". 
bivalência de sentimento em relação à própria profissão e sua dinâmica. Essa relação, muitas vezes marcada por amor e ódio, pode se voltar contra os próprios professores na mesma proporção, de realização ou autoagressão. Vejamos o relato a seguir como ilustração desse apontamento:

Tem sala, tem turma, que às vezes você tem que ser mais, assim, incisiva, mais bruta, né, falar de uma forma assim. Então, às vezes, a gente fala desse jeito. As vezes a gente usa mais o caminho da doçura. Eu, particularmente, eu sou mais da doçura, sabe, não gosto de perder, assim, o meu 'prume', de alterar o tom de voz. Mas quando a gente, quando isso começa a ter que acontecer, $e$ você reprimi isso, aí a gente vai ficando doente. Oh, você sente. Eu tenho, agora eu tô um pouquinho controlada, dei uma controlada, mas vindo pra cá, os dias que eu venho pra cá, eu tenho disenteria. Só os dias que eu venho pra cá. E eu sinto um mal-estar. Eu venho pra cá quarta. Terça eu já tô passando mal, eu penso assim: 'Ai meu Deus, aquela sala de aula, aquele povo, aqueles meninos, aquela sala específica.' 'Ai meu Deus, agora eu vou.' 'Ai, que bom. Chegou a hora do recreio; tem só mais dois horários.' 'Vou cumprir; vou embora. Vou dar minha aula e vou embora', sabe. Porque chega um ponto que você pensa assim: 'Tô cumprindo, menos um dia.' Porque vai ficando muito difícil. Então, assim, isso é razão de adoecer, sim. Professor adoece porque você vai sentindo que toda aquela frustração, ela vai materializando, né. (SIMONE, grifo nosso).

Vejamos como esse relato evidencia uma professora que está sofrendo, e que esse seu estado é muitas vezes externalizado pela somatização, mas, a princípio, mostra-se internalizado pela renúncia da manifestação de algo importante em que ela sente a obrigação de calar. A própria professora reconhece que, quando não manifesta seus impulsos hostis contra os alunos, essa repressão, essa internalização, a faz adoecer. Toda a entrevista foi marcada por fortes indícios do mal-estar. No entanto, mais adiante a professora revelou seu desejo em permanecer na profissão e na mesma dinâmica:

[...] Mas olha só, [cita o nome da pesquisadora], eles não me deixam ao menos falar com eles.
Teve uma última, um último embate. Assim, não foi embate porque eu também não vou, eu falo, não vou bater de frente no sentido de eu me machucar, eu me desgastar, até, às vezes, até fisicamente, né. Não quero perder a minha razão de bater boca com aluno, essas coisas. Eu prefiro ir embora ofendida do que pensar que eu dei um motivo pro aluno ter se sentido ofendido. (SIMONE).

Eu tô satisfeita com ele [trabalho] porque eu acho que eu faço por onde, entendeu? Tô satisfeita comigo, da minha coragem de permanecer [a professora começa a chorar], da minha vontade de permanecer. (SIMONE).

A professora afirmou que prefere não romper com a ética social e, assim, escolhe continuar renunciando impulsos importantes, o que, num movimento natural, leva a uma ação contra si mesma. No ponto de vista freudiano, a discussão sobre a repressão dos impulsos agressivos, orientada pela adaptação à civilização, indica uma via de interiorização da agressividade. Freud (1996c, p. 116) afirma que, "via de regra essa cruel agressividade espera por alguma provocação, ou se coloca a serviço de algum outro intuito, cujo objetivo também poderia ter sido alcançado por medidas mais brandas".

Alguns professores citaram situações em que romperam o vínculo com cargos que os faziam sofrer, exonerando-se, pedindo demissões numa tentativa de se desvincular das situações de exercício do magistério que lhes causavam sofrimento. Contudo, a maioria dos entrevistados relatou não desejar romper com a atual dinâmica de sua prática profissional. Será que não há um gozo nesse exercício profissional que ora causa angústia, ora é uma fonte de satisfação? Acostumados e cobrados a gozar constantemente, os docentes parecem ter assumido a dinâmica do gozo em sua profissão.

A autoagressão se confunde com a ambivalência de querer estar em sala de aula e sofrer por isso. Está relacionada, ainda, à culpa por não dar conta, por não sustentar de maneira adequada a escolha da docência como profissão. Por isso, alguns professores relataram ser 
confortador o fato de ouvir experiências de mal-estar de outros colegas, pois isso redime, um pouco, a culpa que sentem por suas dificuldades, por seu sofrer.

Lidar com essa culpa pode ser algo muito difícil para os professores, razão pela qual muitos deles, conscientemente, eximem-se dessa parcela de culpa pelos resultados não satisfatórios do trabalho, atribuindo exclusivamente aos alunos, suas famílias ou a questões políticas a responsabilidade pelo seu mal-estar.

Não é coincidência o fato de que o processo de avaliar foi eleito, repetidas vezes, como a atividade que menos gostam na profissão, porque a grande maioria dos professores tem a consciência de que na avaliação eles também são avaliados, de que suas funções, enquanto docentes, também estão envolvidas nos resultados avaliativos. Um resultado ruim os coloca diante da culpa de talvez não exercerem com a eficiência desejada sua profissão.

\section{Considerações Finais}

Ao longo do texto, esforçamo-nos em discutir o mal-estar docente a partir da perspectiva psicanalítica, apresentando dados de uma pesquisa, que apesar de relativamente longínqua, fornece contribuições extremamente atuais para a análise do mal-estar entre professores.

Os indícios de mal-estar que nos intrigavam no começo da pesquisa foram corroborados quando convidamos os professores do ensino médio a darem voz ao mal-estar por meio das entrevistas. Fomos prontamente atendidos nesse chamado por muitos professores, que transmitiam a nós, mesmo antes das entrevistas, suas angústias em relação ao exercício profissional.

Os dados revelaram que há muitas razões associadas ao mal-estar entre os professores entrevistados. Além de questões relacionadas à carreira, como condições de trabalho e valorização profissional, outras questões revelaram a profunda relação do mal-estar com possíveis falhas do processo educacional enquanto operador de interdição de comportamento hostis dos alunos, e sentimentos de culpa, ora traduzidos por processos de autoagressão entre professores. Esses temas ensejam a Teoria Psicanalítica como fundamental para a compreensão do mal-estar entre professores.

O que une todas essas razões para o mal -estar é o fato de que todos esses embates possuem raízes muito bem fincadas no complexo movimento da vida em comunidade. Essa convivência comunitária, que necessitamos e desejamos por mais sofrer que cause, é terreno de inúmeros conflitos, que ora eclodem como sofrimento psíquico, ora eclodem como devoção aos excessos, ou outros sintomas contemporâneos.

Enquanto Freud concentra sua análise no homem enquanto ser social, analisando os processos de civilização e a forma como o homem se apropria desse processo de construção da vida em sociedade, através do surgimento do superego, esforçamo-nos em compreender os contornos desse processo no contexto escolar.

Naturalmente, esses dilemas sociais e culturais que atingem a sociedade alcançam a escola, seus profissionais e alunos, constituindo-se em razões para o mal-estar. Nesta pesquisa, percebemos como esses dilemas atingem os professores do ensino médio, e também notamos como muitas vezes são dilemas que os paralisam e os fazem sofrer.

Disso depreendemos que os professores sofrem mal-estar por reprimir impulsos, por desejar manifestar, sofrem quando aqueles que deveriam reprimir não o fazem, ou seja, há um cunho de sofrimento oriundo do cimento do convívio social, que requer a regulação e a repressão do outro, pois sem isso sua segurança na vida comunitária fica ameaçada.

Se o educador é alvo de impulsos hostis, sua autoridade é questionada, não encontra o reconhecimento esperado na profissão, não vê sentido no magistério. Em todos esses impasses temos razões para o mal-estar docente.

A conclusão a que chegamos nesta pesquisa é que grande parte dos professores entrevista- 
dos não têm conseguido lidar com esses impasses no campo educacional, ou seja, investidos da expectativa de serem agentes de interdição dos alunos, se frustram por não conseguirem, além de terem que lidar com os próprios sentimentos de culpa que decorrem de suas experiências formativas frustradas.

Para superar esses impasses, é preciso considerar que a discussão em torno do mal-estar docente precisa ser desmistificada, avançando para a compreensão de como o mal-estar tem sido vivido e experimentado em nossa sociedade. Aqui surge uma problematização sobre o mal-estar, que assinalaremos segundo as proposições do psicanalista Márcio Peter de Souza Leite (2008), que afirma: "Se não há cura do mal-estar, para que serve interpretar a cultura?", e que de forma simples responde: "o psicanalista não pode prometer uma cura do sintoma social, nem um laço social adequado, nem satisfação, mas apenas uma ética outra que a que identifica o bem com o bem-estar".

\section{REFERÊNCIA}

ADORNO, Theodor W. Tabus acera do magistério. In: ADORNO, Theodor W. Educação e emancipação. Tradução de Wolfgang Leo Maar. Rio de Janeiro: Paz e Terra, 1995. p. 97-117.

AGUIAR, Rosana Márcia Rolando; ALMEIDA, Sandra Francesca Conte de. Mal-estar na educação: o sofrimento psíquico de professores. Curitiba: Juruá, 2008.

BIRMAN, Joel. Mal-estar na atualidade: a psicanálise e as novas formas de subjetivação. 7.ed. Rio de Janeiro: Civilização Brasileira, 2009.

DE PAOLI, Cynthia. Superego contemporâneo: exceção e regra. Tempo psicanalítico, Rio de Janeiro, v. 37, p. 39-56, 2005.

ESTEVE, José Manuel. 0 mal-estar docente: a sala de aula e a saúde dos professores. Tradução de Durley de Carvalho Cavicchia. Bauru, SP: EDUSC, 1999.

FREUD, Sigmund. Totem e tabu. In: FREUD, Sigmund. Edição Standard Brasileira das obras psicológicas completas de Sigmund Freud, vol. XIII. Tradução de Jayme Salomão. Rio de Janeiro:
Imago, 1996a. p. 21-162.

FREUD, Sigmund. 0 futuro de uma ilusão. In: FREUD, Sigmund. Edição Standard Brasileira das obras psicológicas completas de Sigmund Freud, vol. XXI. Tradução de Jayme Salomão. Rio de Janeiro: Imago, 1996b. p. 15-63.

FREUD, Sigmund. 0 mal-estar na civilização. In: FREUD, Sigmund. Edição Standard Brasileira das obras psicológicas completas de Sigmund Freud, vol. XXI. Tradução de Jayme Salomão. Rio de Janeiro: Imago, 1996c. p. 73-148.

HERRMANN, Fabio. 0 que é psicanálise - para iniciantes ou não. São Paulo: Psique, 1999.

HERRMANN, Fabio. Pesquisando com o método psicanalítico. In: HERRMANN, Fabio; LOWENKRON, Theodor (org.). Pesquisando com o método psicanalítico. São Paulo: Casa do Psicólogo, 2004. p. 43-83.

INSTITUTO BRASILEIRO DE GEOGRAFIA E ESTATÍSTICA (IBGE). Pesquisa Nacional por municípios. Dados sobre ensino - matrículas, docentes e rede escolar do ano de 2007. Rio de Janeiro; 2008. Disponível em: http://www.ibge. gov.br/cidadesat/topwindow.htm?1. Acesso em: 09 set. 2011.

JESUS, Saul Neves de. Desmotivação e crise de identidade na profissão docente. Revista Katálysis, Florianópolis, v. 7, n. 2, p. 192-202, 2004.

LEITE, Márcio Peter de Souza. Lacan com Marx: clínica da cultura. Ensaios sobre a psicanálise e o social. 2008. Disponível em: http://www. marciopeter.com/links2/ensaios/ensaios_ lacanmarx.html. Acesso em: 19 fev. 2020.

LEVISKY, David Léo; TAILLE, Yves de La. Mal-estar na educação. In: MACEDO, Lino de; ASSIS, Bernadete Amêndola de (org.). Psicanálise e pedagogia. São Paulo: Casa do Psicólogo, 2002. p. 101-123.

MATTEO, Vincenzo Di. Nietzsche e Freud: pensadores da modernidade. Revista de Filosofia Aurora, Curitiba, v. 23, n. 33, p. 269-286, jul./ dez. 2011.

MIRANDA, Margarete Parreira; SANTIAGO, Ana Lydia. O mal-estar do professor frente à "criança-problema". In: COLÓQUIO LEPSI IP/FE-USP: Psicanálise, educação e transmissão, 6., 2006, São Paulo. Anais[...]. São Paulo: USP, 2006. Disponível em: http://www. proceedings.scielo.br/scielo.php?script=sci_arttext \&pid=MSC0000000032006000100048\&lng=en\&n rm=abn. Acesso em: 13 fev. 2020. 
ORGANIZAÇÃO MUNDIAL DA SAÚDE. CID-10 classificação estatística internacional de doenças e problemas relacionados à saúde. 10. ed. rev. v. 3. São Paulo: EDUSP, 2004.

PEREIRA, Marcelo Ricardo. Mal-estar docente e modos atuais do sintoma. In: MARIGUELA, Marcio; CAMARGO, Ana Maria Faccioli de; SOUZA, Regina Maria de (org.). Que escola é essa?: anacronismos, resistências e subjetividades. Campinas, SP: Alínea, 2009. p. 37-59.

RAULET, Gérard. As duas faces da morte: sobre o estatuto da agressividade e da pulsão de morte em o mal-estar na civilização. In: RIDER, Jacques Le. Et al. (org.). Em torno de o mal-estar na cultura, de Freud. Tradução de Carmen Lucia MontechiValladares de Oliveira e Caterina Koltai. São Paulo: Escuta, 2002. p. 71-93.

VOLTOLINI, Rinaldo. Educação e psicanálise. Rio de Janeiro: Zahar, 2011.

Recebido em: 25/07/2020

Revisado em: 09/12/2020

Aprovado em: 11/12/2020 